\title{
Digital image processing techniques as a tool for evaluating and mapping patinas on granite monuments
}

\author{
R. Bustamante \\ Escuela Técnica Superior de Arquitectura, Universidad Politécnica de Madrid, Spain \\ N. Prendes \\ Cedex-Ministerio de Fomento. Madrid, Spain
}

\begin{abstract}
Monument conservation is related to the interaction between the original petrological parameters of the rock and external factors in the area where the building is sited, such as weather conditions, pollution, and so on. Depending on the environmental conditions and the characteristics of the materials used, different types of weathering predominate. In all, the appearance of surface crusts constitutes a first stage, whose origin can often be traced to the properties of the material itself. In the present study, different colours of "patinas" were distinguished by defining the threshold levels of greys associated with "pathology" in the histogram. These data were compared to background information and other parameters, such as mineralogical composition, porosity, and so on, as well as other visual signs of deterioration. The result is a map of the pathologies associated with "cover films" on monuments, which generate images by relating colour characteristics to desired properties or zones of interest.
\end{abstract}

\section{INTRODUCTION}

Granite is a major construction material in Spanish historical building and monuments, whose use dates to prehistoric times (megalithic monuments), together with carbonated rocks and sandstone. This type of rock, granite, is not only one of the most abundant in the northwestern part of the peninsula, but also one of the hardest and most durable.

Complex weathering processes are triggered by interaction of natural stone building materials with environmental factors, such as climate and the biosphere. However, human activity causes external factors (pollutions) and natural water to amplify the natural weathering processes.

One of the most conspicuous alterations is the chromatic change associated with external modifications taking place in rock, in this case granite, to attain equilibrium in and adapt to the new environmental conditions. The selective nature of certain pathologies is conducive to viewing the monument, once built, as an ecosystem with its own microclimate.

The position of each ashlar is, then, a determinant of alteration and consequently of the service life of the structure.

The need to prevent or minimize this damage has led to a series of methodologies for establishing its origin as well as to a focus on the phenomena and causes of deterioration to which natural stone is exposed in its new location.

Hence the formulation of detailed maps of the monument, including lithologies, pathologies, replacements, rehabilitations and so on, provide a more accurate idea of the potential problems that may be posed. And all this information is, moreover, essential to optimizing costs and organizing the stages to be addressed in sound restoration.

The maps of certain elevation views had in fact been plotted manually for some of the studies of stone alteration. This rendered the project fairly unviable, for it would have entailed "drawing" each view practically stone by stone, to subsequently add the problems affecting each.

Digital image processing constitutes a powerful and objective tool in this regard, for all the possible information can be retrieved and quantified from photographs.

Maps of alterations, pathologies and interventions, along with the associated databases, could thereby be built. This made it possible to conduct speedy, reliable and time-sequenced analyses as well as to map evolution, extension, impact and essentially any other parameter imaginable.

Lastly, this tool can now be used to draw up maps showing the risks and state of repair of buildings of public interest. 


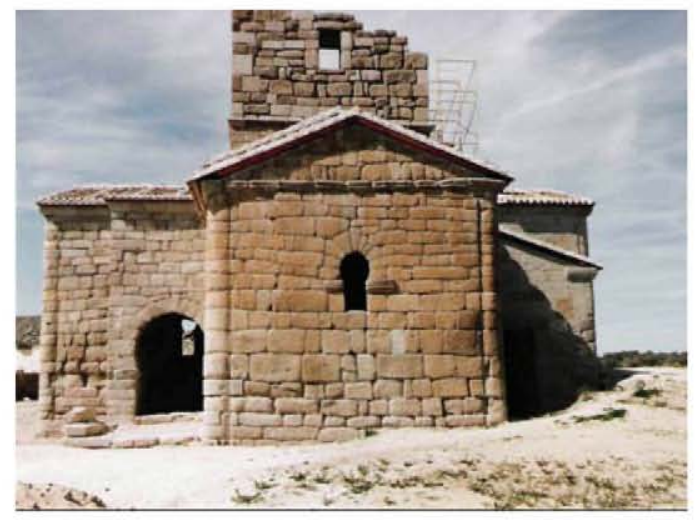

Figure 1. Ashlar morphology in granite and their colour (Southwest façade Santa María de Melque).

\section{PETROGRAPHIC EXAMINATION OF GRANITIC ASHLAR}

All the buildings studied in this article are made of granite or granodiorite associated with the Hercynian massif. These materials are extremely weather-resistant and their low porosity, highly crystallized structure and geochemical composition have won them esteem as ideal building materials.

Despite the existence of zoning in their mineralogy and petrographic composition, from the standpoint addressed here (identification of crust-covered surfaces), they can be viewed as homogeneous and stable rocks whose physical-chemical properties remain essentially unaltered over time.

These particularities greatly facilitate the methodology to be developed from the vantage of image digitization techniques.

The key parameter to be considered is heat. A definition of the chromatic coordinates and their variations can be used to identify damp (such as in the case of Santa María de Melque at Toledo, fig. 1), due to which the ashlars gradually grow darker from thermal fatigue and component (feldspars are most readily altered, owing among others to their greater abundance, much higher than micas) dissolution or conversion to less stable phases.

Another possible scenario is, as in the present case, the development of lichens and microorganisms (orange patinas), initially regarded to be "protective", or of pollutant patinas or crusts generated by carbon dioxide, particles from coal-fired power plants (fly ash) or other physically and chemically active materials.

Some of these may interact with certain mineral phases (such as pyrites, minority but common constituents of granite, or calcopyrites, marcasites and so on), which "convert" to new mineralogical and

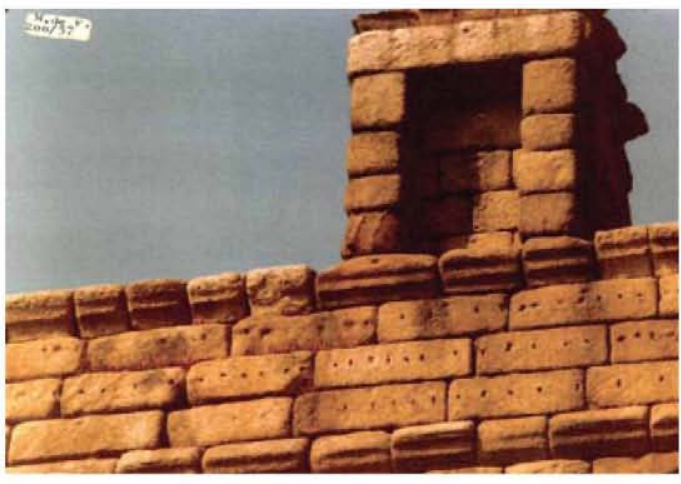

Figure 2. Natural orange colour of the granite (East façade of aqueduct at Segovia).

potentially aggressive phases. Highly disruptive gypsum or ettringite, which spur deterioration and ruin in this type of granite facades, would be examples of such products.

Lastly, be it said that studying and monitoring colour is useful for defining the type of treatment to be pursued in such monuments (a methodology documented on the occasion of the restoration of the aqueduct at Segovia, fig. 2), when the chromatic coordinates defined the type of chemical product to be applied to maintain the aesthetics and harmony of this heritage monument.

\section{PATHOLOGIES}

The evaluation and diagnosis of the pathologies, suffered by historical buildings concentrated on determining petrographical parameters, the nature of the constituent, etc. Moreover, considering the monument as a whole, other authors have evaluated the damages suffered using the false colour technique and comparing photographs taken over the years, managing to distinguish between healthy and altered areas on the surface, according to the texture of the materials and their pathologies. Additionally, in some case, they also used ultrasonic images.

Depending on the environmental conditions and the internal characteristics of granite different types of weathering predominate: efflorescence, plates, black crust, orange crust, etc.

Of all these phenomena, the present article focuses on the crusts and patinas that grow on granite surfaces, most of which have a microbiological origin and - in principle - protect the stone.

The first change is the appearance of a type of crust that adopts the form of a variation in colour, readily identifiable with digital image processing techniques and not, in principle, regarded to be 


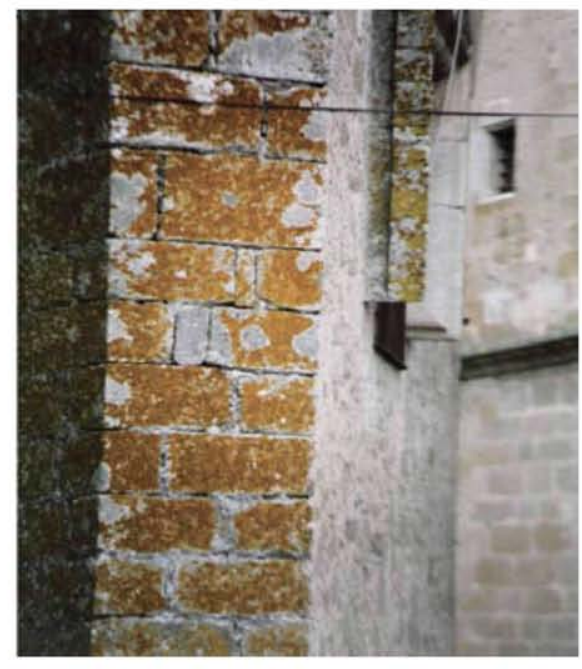

Figure 3. Patinas aspect in granite and their colour of cutwater (Northwest façade of bridge at Cáceres).

aggressive. Only alterations in the intrinsic properties of granite, such as porosity, or the appearance of disintegration give cause for concern, as a general rule. Nonetheless, such pathologies are difficult to address, for while the crust may be eliminated, the treatment involved is often more aggressive than the pathology itself.

\section{DIGITAL IMAGE PROCESSING TECHNIQUES}

The development of graphical data processing systems permits the combination on the one hand of the surface damage to the monument, noted by digital analysis, and on the other the information deriving from other techniques (thermography, photography, etc.).

By means of this, then, we can generate new layers of information (by assimilating all the previous information) or images (the equivalent of the multi-images techniques).

\subsection{Digital image processing}

Digital image processing can be defined as the mathematical operations to which an image is subjected to obtain another, modified one, that conserves certain characteristics of the original, but which however contains additional information that can be interpreted by a computer.

The study of the monument starts with the photographs and the technical drawing of the "original plans" showing the position of each ashlar.

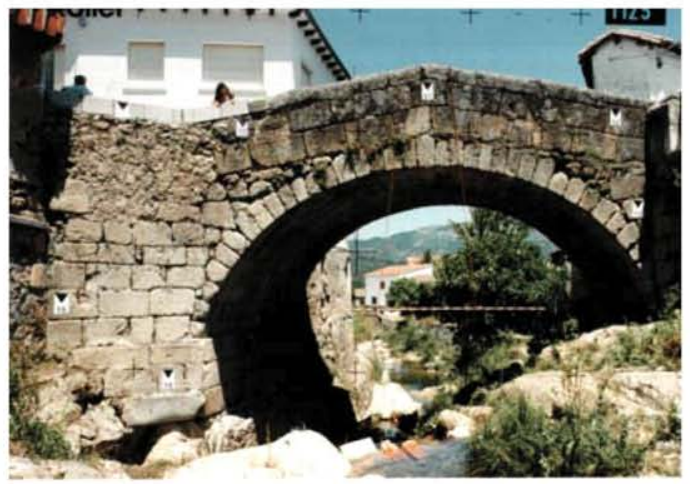

Figure 4. Granite bridge at Cáceres (East facade).

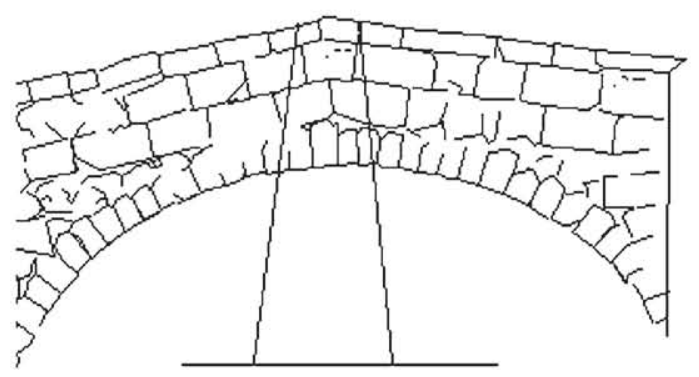

Figure 5. Contour ashlars by photogrammetry techniques.

\subsection{Image capture and enhancement}

In this case, they both have been digitized using a scanner, correcting by slight distortions produced during the process, and adapting and referencing them in order to coordinate the scales and facilitate the overlap process, as shown in figures 4 and 5 . Also, the image is processed with a $\mathrm{L}($ look $) \mathrm{U}(\mathrm{Up}) \mathrm{T}($ Table) or false colour technique to obtain the texture of the ashlar stones.

Another image derived with of photogrammetry is shown in fig. 8. Scaled and calibrated, this image is, therefore, the reference for the first process of digital analysis?

From the digitized image of the drawing we learn the original distribution and form of the monument ashlars. The contour lines correspond to the edges of the ashlars and will have grey levels near zero. From the restoration of the image we have to apply matrix filters and spread the histogram to the full range.

Digital restoration was carried out by applying a series of algorithms for modifying the grey scales (histogram), adjusting contrast (increases or decreases by varying the width of the display range), reducing noise, enhancing borders, interpolating and pseudocolouring, and so forth. 


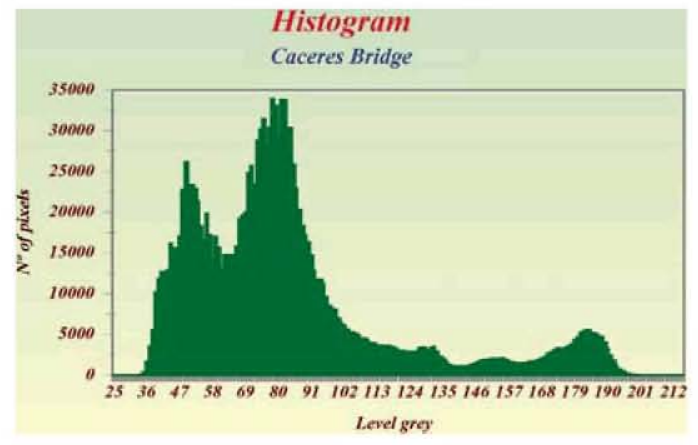

Figure 6. Histogram of the bridge image.

Is should be pointed out that such enhancement operations add no new information to the image, but rather increase the dynamic range of the desired characteristics so that in subsequent stages of image processing, they can be more easily located and modified.

The restoration of the image, when the photograph of the bridge is digitized, is performed by studying the frequency histogram (fig. 6) of grey level. The structural characteristics of the ashlars forming the bridge are revealed by applying a standardization algorithm that enhances contrast linearly to the maximum and minimum possible levels of grey in the image (i.e., 0 to 255) and subsequently performing matrix highpass filtering (fig. 7). This highlights ashlar contours.

\subsection{Image thresholding}

Beginning with the image resulting from the first image restoration procedure, we subdivided and classified the information obtained to ultimately arrive at the desired conclusions. In short, this process, denominated "thresholding", generates an image by recognizing some areas, textures, forms, etc., with the desired properties or zones of interest (the procedure consists of delimiting a range of previously defined grey values, and reassigning to this range an output value of 1 , and setting the rest to 0 , as shown in the fig. 8 .

The result is an image which allows a better threshold setting in the segment process, getting a binary image which corresponds to the ashlars in their altered present state.

The Boolean operator type AND is applied to the two images of the ashlars; the original (fig. 4) and photogrammetric (fig. 5) and as derived from digital images techniques (fig. 7). It extracts information common to both and the differences are deduced. These occur principally on the edges and sometimes are especially significant in the arch.

The Boolean operator NOT (this inverts the image showing the area of each ashlar) is applied to quantify the phenomenon of material loss or grain disintegration

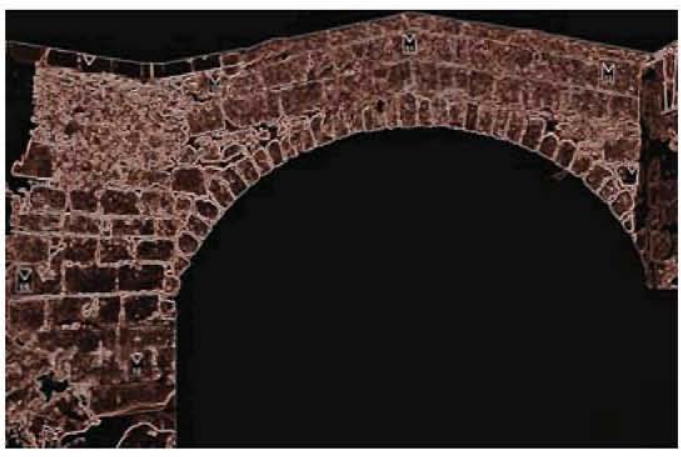

Figure 7. Granite bridge highpass filter.

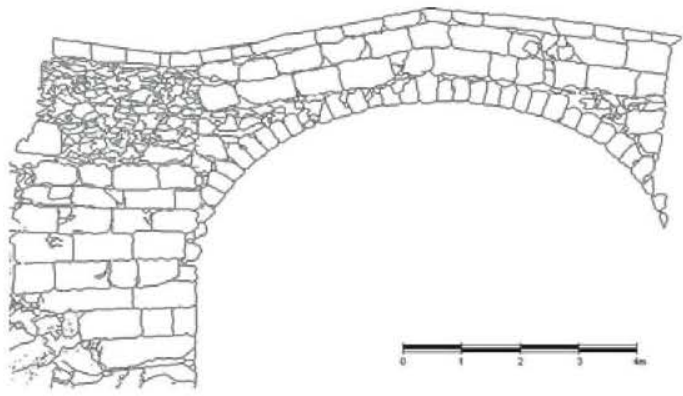

Figure 8. Contour ashlars by tresholding process. Calibrated image.

and the Boolean operator XOR (this extracts the information which is not common) highlighting pixels.

The ashlars are classified by their patinas (three in this case) applying line profiles for each. In these profiles we give the statistical parameters (maximum and minimum value) of the setting in order application in the thresholding process. The statistical treatment gave rise to some ashlar overlapping in the grey level limits. This overlap caused confusion in the segmentation process (due to its grey common levels) and therefore in the adequate discrimination of each ashlar. This problem was solved by using grey level discrimination that identifies each phase via two bands on the colour histograms.

On three bands of the image (Red, Green, Blue) we sought those with least overlap. For example in the case of patinas the setting thresholds were taken from channel $\mathrm{R}$ while background granite was distinguished in channel G.

\subsection{Quantification of results}

The results are three binary images with the grey levels of each pathology. Into each image will be reassigned a new different grey level. Each image is 
reassigned a new grey value and via combination a single image is obtained that integrates all three levels. The result is a classified image with some colour; each identifies a different type of weathering (crust orange, black, etc.).

However, it must be pointed out that there are areas remaining in the classified image which are indistinctly assigned to two different zones. The solution adopted was to amplify these conflictive zones (zoom up), apply a lineal algorithm and threshold anew with the limit deduced from this last process. After this process was completed these subimages were reduced (zoom down) and integrated into the original.

In this case, those ashlars which caused problems, and so had to be reclassified using this process, represent $15 \%$ of the bridge. This corresponds to the tympana where there is a greater evenness of grey level making up that part of the image.

The comparison between the image resulting from this whole process of lithological classification and the original demonstrate that there are still some ashlars $(8 \%)$ which have not been correctly classified. This must be corrected interatively by reassigning the adequate colour.

From this process we obtain a second image, which corresponds to another layer of information, and in which the bridge patinas can be identified.

In order to obtain a map of the alteration apparent in the bridge two different processes are applied to the image now restored.

The first involves the change of histogram at the grey level values, concentrating on the lower levels to put in evidence slight colour changes in the material, achieve a better differentiation of sometimes subtle variations in grey levels. After this, the total image is progressively zoomed to a resolution of $50 \times 50$ pixels increasing the effectiveness of the differentiation. This process scans the areas affected by colour changes in the ashlars (as is the case of blackening crust and patinas (orange or decoloured). Distinguishing between these two is impossible using the computer, so they have been included in the same group.

The second process involves operating on the geometric details of the image distinguishing limits between similar grey level (area operations). The filters applied in this case are of the standardized Sobelgradient type (which only highlight the existence of contours within the image).

With this algorithm both the contours and the textures of each ashlar are extracted. The result is an image which after thresholding provides the geometric characteristics (understood to be the irregularities of each ashlar, such as edges, grooves, etc.).

The image of the bridge ashlars would reflect only the internal properties of each stone, which are ultimately responsible for the alterations and textures exhibited. The difference between one type of texture and the other can be met by applying binary morphological algorithms. In this way and using this image we can eliminate long objects by expertly sifting (whose shape factor is below 0.3). The result is a new classified image.

\section{MAPPING PATHOLOGIES}

This layer is what we call generated or deduced images, which contains graphical information associated with a relational database and which can form combinations with other images or with its own components.

The layers of information are made up of images elaborated by digital processing. We assign the level zero to a thinning image (mask image), which is the one containing the reference information for the rest of the maps: in other words, that shows us the ashlars exactly as they are nowadays. This level shall be repeated in the rest of the layers we create afterward. This level is the one which acts as a point of reference for the connection among these layer, in shared areas of working memory (superimposing information).

The lithological layer is derived from the classified image of the materials. It is used as an area of memory to connect to the database containing the petrophysical and petrographical properties, which are derived using other methods beyond the scope of this paper. As a consequence each lithology is identified by a specific, single grey scale.

The petrographical, petrophysical and other properties are entered in a database whose identification and entry code is the same, corresponding to the identifying grey levels of that lithology. In this way when the cursor is moved across the monitor screen and a certain pixel is selected the corresponding "colour" is real and the database is accessed. A dialogue box is opened and the pixel properties are shown. Likewise, a second possibility is to introduce "via the keyboard" a range of values for a certain property (porosity, for example) which distinguishes the identifying colours of the corresponding lithology, representing on the screen the colour that falls within that range.

With this technique permits a cartographic map of petrophysical and water and petrographycal properties can be generated. This latter possibility would use the mask or base image to reflect the result, generating theme property maps of the database values. Each of them, so generated, may be isolated and added to a new layer of information.

The combination of these images retrieved in areas of memory, with another layer (lithological or alteration graph) provides maps of intersection areas which enable us to relate the petrophysical, water and petrogaphical properties to alterations, inconsistencies, and so on. 
This is extremely useful when the time comes to propose restorations, renovations or substitutions of some ashlars for others.

These tree layers of information were combined, taking account of the nature of the bridge (granite) and the rest of building studied here, its state (alterations), and the orange crust on the material. For this specific case and by way of example, the result is a map of pathologies associated with lichens. The processor marks the ashlars that need to be substituted, restored (treated with some product or cleaned) and those that show no sign of serious damage.

\section{CONCLUSIONS}

The possibility of combining digital image processing techniques to generate theme maps, with a database containing petrophysical and petrographical parameters constitutes a data processing system with which specialized maps (of alterations, lithologies ...) can be generated. These facilitate the interpretation and evaluation of the pathologies of the monuments in question.

The use of this system on some Castilian monuments (Spain) has led to the classification of their ashlars, giving us a first approximation of which should be treated, replaced or maintained, as well as providing us with theme maps of great interest in the tasks of renovating, cleaning, consolidating, and so on, with significant savings in time and organization of the phases involved.

\section{REFERENCES}

Angel, Ma . C., Martínez, B., Prendes, N. \& Rodríguez, F. 1995. Monuments Deterioration Evaluation, Using Digited Images. A Methodology. In Materiales de Construcción. Vol 45, $\mathrm{n}^{\circ}$ 240: 37-46.

Angel, $\mathrm{M}^{\mathrm{a}}$. C., Martínez, B., Prendes, N., Rico, J. M. \& López, A. 1995. Caracterización Petrográfica y petrofísica de los Sillares del "Puente Viejo" de Molina (Guadalajara) con vistas a su posterior restauración. (Edita CEDEX) Rev. Ing. Civil, $\mathrm{n}^{\circ}$ 96.: 51-65.

Angel, $\mathrm{M}^{\mathrm{a}}$. C., Martìnez, B., Rodrìguez, F. \& Prendes, N. 1997. Obtención de datos morfométricos de las alteraciones de la fachada principal de la Iglesia de San Lorenzo, en la Escalerona. (Edita CEDEX) Rev. Ing. Civil, $\mathrm{n}^{\circ}$ 99.: 42-56.

Ascaso, C. \& Wierzchos, J. 1996. Study of the Weathering Processes of Granitic Micaceous Minerals by Lichen Activity. pps. 411-416. In Degradation and Conservation of Granitic Rocks in Monuments. Edición a cargo de M. A. Vicente, J. Delgado y J. Aceves. Research Report $n^{\circ} 5$.

Barral, X. 1998. La Alta Edad Media. De la Antigüedad tardía al año mil. Ediciones Taschen. Vol. 3.

Begonha, A. \& Sequeiro, M. A. 1996. Characterization of Black Crust and ThinBlack Layer in Granitic
Monuments: The Role of air Polution. Pps 121-126. In Degradation and Conservation of Granitic Rocks in Monuments. Edición a cargo de M. A. Vicente, J. Delgado y J. Aceves. Research Report $n^{\circ} 5$.

Bel-Lan, A. 1989. Análisis de Parámetros Petrográficos mediante Proceso Digital de Imágenes. Tesis Doctoral. Universidad Autónoma de Madrid.

Caballero, L., Arce, F. y Feijoo, S. 1996. Fotogrametría y Análisis Arqueológico. Rev. de Arqueología (año XVII, $\mathrm{N}^{\circ} 186$ ): 14-25.

Cuellar, J. 1998. Arquitectura Romana en Españ a. Editorial Edimat. Pgs. 190.

Delgado, J. Coord. 1996. Conservation of Granitic Rocks with Application to the Megalithic Monuments. Project STEP-CT-90-110, pgs. 161242. In Degradation and Conservation of Granitic Rocks in Monuments. Edición a cargo de M. A. Vicente, J. Delgado y J. Aceves. Research Report $\mathbf{n}^{\circ} 5$.

Domingo, A. 1993. Tratamiento Digital de Im genes. (Ediciones Anaya). 125 pgs.

Esbert, R ${ }^{\mathrm{a}} \mathrm{M}^{\mathrm{a}}$., García, J. C., Martínez-Nistal, A, Ordaz, J., Valenzuela, M., Alonso, F. J. y Suá rez de Centi, C. 1992. El proceso Digital de Imágenes aplicado a la Conservación de la Piedra Monumental. Un ejemplo: Santa María del Naranco. Rev. de Arqueología (año XIII, $\mathrm{N}^{\circ} 139$ ): 7-12.

Esbert, $\mathrm{R}^{\mathrm{a}} \mathrm{M}^{\mathrm{a}}$ \& Marcos, $\mathrm{R}^{\mathrm{a}} \mathrm{M}^{\mathrm{a}}$. 1983. Las Piedras de la Catedral de Oviedo y su Deterioración. Edita: Colegio Oficial de Aparejadores y Arquitectos Té cnicos de Asturias.

Esbert, $\mathrm{R}^{\mathrm{a}} \mathrm{M}^{\mathrm{a}}$ \& Montoto, M. 1986. Digital Computering of Microscope Images in Petrographic Investigation of Stone. In ICOMOS. Group Petrography. Pavia Meeting: $25 \mathrm{pgs}$.

Esbert, R ${ }^{\mathrm{a}} . \mathrm{M}^{\mathrm{a}}$, Ordaz, J., Alonso, $\mathrm{F}^{\mathrm{co}}$. J. \& Montoto, M. 1986. Manual de Diagnosis y tratamiento de Materiales Pétreos y Cerámicos. (Edita Col legi d'Aparelladors i Arquitectes T cnics de Barcelona).

Fiztner, B. 1990. Mapping of Natural Stone Monuments. Documentation of Lithotypes and Weathering Forms. Advanced Workshop "Analytical Methodologies for the Investigation of Damage Stones”. Pavia. 24 pgs.

Fiztner, B., Heinrichs, K. \& Kownatzki, R. 1995. Weathering Forms - Classification and Mapping. (Edited by Ernst \& Sohn). Deuchtland. Separata: 41-88.

Fontaine, J. 1992. El prerrománico. Volumen 8 de la serie la España Románica. Ediciones Encuentro. 470 pgs.

Fort, R. 1996. Effects of Consolidant and Water Repellents on the Colour of the Granite Rocks $f$ the Aqueduct of Segovia (Spain). pgs. 1-44. In Degradation and Conservation of Granitic Rocks in Monuments. Edición a cargo de M. A. Vicente, J. Delgado y J. Aceves. Research Report $\mathbf{n}^{\circ} 5$.

García de los Ríos, J. I., Báez, J. M. \& Jiménez, S. 2002. La Piedra en Castilla y León. Edita Consejería de la Junta de Castilla y León). España.

Gonzalez, R. C. \& Wintz, P. 1987. Digital Image Processing. (Edited by Addison-Wesley). London (UK).

Jain, A. K. 1989. (Edited by Kailath, T.) Fundamentals of Digital Image Processing. London (UK).

Maldonado, L. 1999. La Fotografía Aplicada a Proyectos y Obras de Restauración. Tomo 2. Cap. 4. (Ediciones Munilla-Leria). Madrid. 
Martínez-Nistal, A. 1993. Discriminación, cuantificación y Cartografiado de Componentes petrográficos mediante proceso digital de multi-imágenes microscópicas. Tesis Doctoral. Universidad de Oviedo.

Montoto, M., Montoto, L. \& Bel-Lan, A. 1981. Proceso Digital de Micrografías en Petrología. (Edita Universidad de Oviedo).Documentos de Investigación. Departamento de Petrología-Centro de Investigación UAM IBM. 78 pgs.

Montoto, L. 1977. Técnicas Digitales en la Detección Automática de una red hidrográfica. Sem. Int. Sensores Remotos en el desarrollo de los paises. (Mexico): 12 pgs.

Ordaz, J., Pérez-Ortíz, A., Esbert, R ${ }^{\mathrm{a}}$. M ${ }^{\mathrm{a}}$., Martónez-Nistal, A. y \& Alonso, F.J. 1996. Study of The Granite Crack Network by Jeans of Digital Image processing. Pgs. 249-253. In Degradation and Conservation of Granitic Rocks in Monuments. Edición a cargo de M. A. Vicente, J. Delgado y J. Aceves. Research Report $\mathrm{n}^{\circ} 5$.

Prendes, N. 1993. Digitización de imágenes en Arquitectura. Curso de Postgrado. ETSAM.: 45 pgs.

Prendes, N. 1995. Mapeo de Materiales y Daé os. XIII Curso de Estudios de la Construcción. M S-3 Ed. CSIC. 12-48.

Prendes, N. 2004. Digitización de imágenes. (Ediciones Munilla-Lería). (In press): 34-63.

Prendes, N. 2005. Determinación de Parámetros Petrográficos en Cementos y Hormigones por Tratamiento Digital de
Im genes. Tesis Doctoral. Universidad de Oviedo. (Inédita).

Procopio, R. \& Martínez, M. 1996. Anastilosis Virtual. Reconstrucción Infográfica de la Iglesia de San Miguel de Liño. Rev. de Arqueología (año XVII, No 187): 36-45.

Roca, X., Sanchez, X., Serrat, J., Vanrell, M., Villanueva, J. \& Vitriá, J. 1991. Curso de tratamiento y Análisis de Imágenes. Facultat de Ciéncies. Departament d'Informática. Universitat Autónoma de Barcelona.

Vicente, Ma $\mathbf{M}^{\mathrm{a}}$ A. Coord. 1996. Granitic Materials and Historical Monuments: Study of the Factor and Mechanisms of Weathering and Application to Historical Heritage Conservation: Project STEP-CT-90-101, pgs. 1-44. In Degradation and Conservation of Granitic Rocks in Monuments. Edición a cargo de M. A. Vicente, J. Delgado y J. Aceves. Research Report $n^{\circ} 5$.

Tuceryan, M. \& Jain, A. K. 1993. Texture Analysis. (edited by Chen, Pau \& Wang). Handbook of Pattern Recognition \& Computer Vision. Chp. 2.1: 235-276.

Zezza, F. 1990. Computerized Analysis of Stone Decay in Monuments. Advanced Workshop "Analytical Methodologies for the Investigation of Damage Stones". Pavia.: 163-184. 